\title{
CONFIGURATIONS OF TIRE PRESSURE ON THE PAVEMENT FOR COMMERCIAL VEHICLES: CALCULATION OF THE ' $N$ ' NUMBER AND THE CONSEQUENCES ON PAVEMENT PERFORMANCE
}

\author{
Paulo Boulos Filho \\ Paulista University (UNIP), Brazil \\ E-mail:pa.boulos@hotmail.com \\ Hélcio Raymundo \\ Paulista University (UNIP), Brazil \\ E-mail: helcioru@uol.com.br \\ Sivanilza Teixeira Machado \\ Paulista University (UNIP), Brazil \\ E-mail: sivateixeira@yahoo.com.br \\ Antônio René Camargo Aranha Paula Leite \\ Paulista University (UNIP), Brazil \\ E-mail: arcapale@unip.br \\ José Benedito Sacomano \\ Paulista University (UNIP), Brazil \\ E-mail: jbsacomano@gmail.com
}

Submission: 18/12/2015 Accept: 21/03/2016

\section{ABSTRACT}

Road traffic has a high variety of types of vehicles and cargo transported. One of the main difficulties in pavement design is forecasting the changes in traffic over time and evaluating the comparative deterioration power of the various loads with axle and tire settings and different levels of repetition. The road environment in Brazil, as we know, is the main means of the country's cargo transportation. Throughout the 1990s and 2000s the road modal accounted for over $60 \%$ of the total cargo transported in the country leaving the unbalanced Brazilian transport matrix with almost exclusive investments in such means of transportation. 
According to CNT 2012, which conducted a survey in approximately $45 \%$ of the paved network, evaluating the pavement functional conditions, traffic signs and geometry, $46 \%$ of the country's road network has some types of deficiency in the pavement. The goal of this work is to contribute to a better understanding of the complex influence of traffic in the design and service life of the pavement. The load pressure of commercial vehicle tires over the pavement has increased in recent decades. A more apparent effect of this increase in tire pressure would be the change in the pavement- tire contact area which in turn may result in an increase in the contact load between tire and pavement and other harmful effects on the structure. This study aims to determine the effect on the calculation of the $\mathrm{N}$ number, or the number of solicitations of the standard axle on the road pavement, measuring the overload as a percentage of the legal load indicated by a scale. Thus, we calculate how an increase in the overload percentage in comparison with the allowable load will influence the decrease of the calculated durability of the pavement designed for the highway.

Keywords: road; tire; load; damage.

\section{INTRODUCTION}

Roads are the country's primary means of cargo transportation. Over the 1990 s and 2000s this modal accounted for over $60 \%$ of the total cargo transported in the country (IPEA, 2010). Excluding the transportation of iron ore that is made by railway, roads account for more than $70 \%$ of general cargo.

In 1950, roads were responsible for $38 \%$ of the national cargo transportation (BNDES, 2008). When Juscelino Kubitscheck's government defined the Target Plan, roads were prioritized in order to, among other goals, stimulate the manufacturing industry through the auto industry. Since then the Brazilian transport matrix has shown this unbalance, with investments almost exclusively in this type of modal.

The significant dependence of this modal for the Brazilian cargo transportation is emphasized when compared to other countries with similar dimensions. According to Bartholomeu (2006), in the United States, roads account for $26 \%$ of cargo transportation, while in Australia this figure is $24 \%$ and in China only $8 \%$.

According to the National Confederation of Transport (CNT, 2012), the Brazilian road network consists of 1,366,578 km of unpaved roads and $214,414 \mathrm{~km}$ 
DOI: 10.14807/ijmp.v7i5.419

of paved roads, which represents one of the world's biggest road networks. Despite its large extension, only about $13 \%$ of the network is paved.

According to a survey conducted by CNT (2012) in approximately $45 \%$ of the paved network, evaluating functional pavement conditions, traffic signs and geometry, $46 \%$ of the country's road network show some kinds of pavement deficiency.

IPEA (2010) conducted a study to identify bottlenecks and deficiencies of national roads and they concluded it would take 183.5 billion reais in investments to solve the problems and boost the road sector, increasing its efficiency and its impact on the country's economy.

Within this context, it is clear that the country's economy depends on this modal and that Brazilian roads are in poor conditions. Road pavement stands out mainly because it represents the highest costs, either of deployment, restoration and maintenance, as well as providing users a proper traffic-ability with comfort and safety, resisting the actions of traffic and distributing the efforts to its underlying layers so that the entire set leads to savings in fuel costs, risk of accidents, cargo damages, among others.

One of the main factors to determine the pavement's service life is the type and volume of the traffic to which it will be exposed over its lifetime and its project. Therefore, studies are needed to contribute to a better understanding of the complex influence of the traffic on the pavements sizing and service life (MEDINA; MOTTA, 2005).

In order to standardize the measurement of the factors that influence the pavement sizing, combining the current traffic, the projected traffic and the consequences of its use, mainly through commercial loads, on the fatigue of the pavement structure, computer programs were created that verify the project's viability and durability. Among the standards established and accepted by the projects of the National Department of Transport Infrastructure (DNIT) and its state representatives according to the Paving Manual - IPR - 719 (2006) or the IP-DE-P00/001 - Paving Projects of DER/SP, the following parameters were defined: the standard single axle dual wheel of $80 \mathrm{kN}$ and the tire-pavement contact pressure of $0.56 \mathrm{MPa}$. 
DOI: 10.14807/ijmp.v7i5.419

Considering the variation of ambient temperature, the differences of transported loads that generate more or less friction between the tires and the pavement. The absence of automatic pressure calibration equipment in the vehicle, the driver's negligence regarding the equipment calibration and the load allowed by law, as well as the quality of tires, leaks, etc., we can relate the variation of tire pressure on the pavement with the resulting different structure fatigue through a study where loads are altered in the mechanistic analysis program and the structure behavior is verified.

Therefore, the general goal of this work is to analyze the structural condition of a standard pavement used in projects of Brazilian roads with predefined and constant dimensions, changing the tire pressure applied to the pavement used in standard methodology and verifying the effect on the pavement layers through fatigue equations standardized by DNIT.

\section{LITERATURE REVIEW}

According to National Federation of Automotive Vehicles Distribution (FENABRAVE), the commercial vehicle industry starts growing from the year 2000, associated to the growth of the Brazilian economy and the increase in the transport of commodities. Given the high average age of the Brazilian fleet (Trucks: 17.2 years and Buses: 14.4 years), loan portfolios were created to finance and stimulate the commercial vehicle market. Table 1 shows the production by size from 2008 to 2014 .

Table 1: Production by size (units)

\begin{tabular}{lccccccc}
\hline & 2008 & 2009 & 2010 & 2011 & 2012 & 2013 & $2014^{*}$ \\
& & & & & & & \\
\hline Semi-Light Trucks & 6,908 & 4,961 & 7,216 & 8,451 & 2,450 & 4,059 & 2,225 \\
Light Trucks & 29,330 & 31,493 & 41,740 & 50,686 & 24,497 & 32,093 & 27,875 \\
Medium Trucks & 15,553 & 12,968 & 17,690 & 18,358 & 8,448 & 12,340 & 8,291 \\
Semi-Heavy Trucks & 53,292 & 40,024 & 62,813 & 76,977 & 50,671 & 70,917 & 50,474 \\
Heavy Trucks & 58,674 & 31,548 & 60,482 & 68,916 & 46,887 & 67,680 & 51,100 \\
Total & 163,757 & 120,994 & 189,941 & 223,388 & 132,953 & 187,089 & 139,965 \\
\hline
\end{tabular}

Source: CNT (2012) 
DOI: 10.14807/ijmp.v7i5.419

\subsection{Pavement and traffic}

According to Huang (1993), traffic is the main factor when designing a pavement structure. The traffic variable should include load magnitude, the configuration and the number of load repetitions. According to Yoder and Witczak (1975), the main factors to evaluate the structure of a pavement design are the effects of the type of vehicle, traffic volume and the type of vehicle. The type of vehicle should include specific factors such as axle configuration, wheelbase, wheel load and tire inflation pressure.

According to DNIT (2006), trucks are the largest consumers of the pavement structure because they apply the highest loads on its surface. Among the heavy trucks, not all cause the same damage due to the variations in wheel load (static and dynamic), the number and location of axles, the types of suspension, the number of wheels, the type and pressure of tires and other factors. Balbo (2007) adds that road commercial vehicles (trucks and buses) are the ones that actually matter for designing the pavement since light vehicles cause minor damages to the pavement structure when compared to the load of commercial vehicles.

The pavement is a structure of multiple layers of finite thicknesses, implemented over a final surface of earthwork or sub base, technically and economically intended to resist the efforts resulting from vehicle traffic and weather. It is designed and built to resist the volume of motor vehicles under different climate conditions and to improve the rolling conditions in terms of comfort and safety (SENÇO, 1997; BERNUCCI, et al., 2006).

Road traffic is quite diverse in terms of types of vehicles and cargo transported. One of the difficulties to design the pavement is to foresee the evolution of traffic over time and the evaluation of the destructive power, comparatively, of the various loads and different levels of repetition (MEDINA; MOTTA, 2005).

One of the first surveys to collect data about commercial fleet weighing was conducted by Executive Integration of Transport Policies Group (GEIPOT) between 1976 and 1981 and indicated that on Brazilian roads trucks travel with an overload of 10 to $30 \%$ beyond the limits (FERNANDES JR., 1994).

According to Pinto and Preussler (2002), the variations of axle overload and the corresponding destructive effects on the pavements take place exponentially. 
DOI: 10.14807/ijmp.v7i5.419

They point out the importance of avoiding using overloaded vehicles. Regarding the use of the tire, the pavement design guide considers the tire inflation pressure of 750 $\mathrm{kPa}$, however it adds that data from Tasmania indicate that the tire inflation pressure can vary from 500 to $1200 \mathrm{kPa}$ (AL-QADI; ELSEIFI, 2007).

Kawa et al. (1997) conducted a survey for the Texas Department of Transportation evaluating the concept of load equivalency used by the AASHTO (1972 and 1983). The work points out that determining the load equivalency factors (LEFs) is essential to prepare new pavement projects and existing pavement rehabilitation. The incorrect evaluation of the damage caused by axle load on pavements can result in early failure and raise costs. On the other hand, an overestimate can result in unnecessary expenses, taking funds from other projects.

The following factors should be analyzed to determine if they have any effect over the LEFs: i) increase of tire pressure; ii) new suspension systems; iii) new tire widths such as wide base; iv) new axle configurations, such as tandems and dual tandems; v) environmental factors.

In the road test of The American Association of State Highway OfficialsAASHO, the tire inflation pressure varied from 520 to $550 \mathrm{kPa}(75-80 \mathrm{psi})$. Today trucks usually use tires with pressure ranging from 600 to $800 \mathrm{kPa}$ (85 to $115 \mathrm{psi}$ ) and, in some cases the tire pressure can reach 900 to $1000 \mathrm{kPa}$ (130 to $145 \mathrm{psi}$ ). Literature review shows that high tire pressures can potentially cause more damages to the pavements.

According to Feng (2005) the tire pressure of commercial vehicles has increased in recent decades. A more visible effect of increasing tire pressure would be the reduction of the tire/pavement contact area, which in turn can result in an increase of the tire/pavement contact and another damaging effect on the structure.

\subsection{Types of Brazilian road traffic and their characteristics}

The Brazilian legislation establishes some parameters for the circulation of commercial vehicles on roads, including: Law 9.503/97 Brazilian Traffic Code (BRAZIL, 2015); CONTRAN Resolution 210/06; CONTRAN Resolution 211/06; DENATRAN Decree 63/2009; Lei 7.408/85; CONTRAN Resolution 258/07 and CONTRAN Resolution 365/10. 
DOI: 10.14807/ijmp.v7i5.419

Within the scope of the present research, the Brazilian Traffic Code establishes the following provisions:

- In order to travel on roads the vehicle must comply with the limits defined by CONTRAN regarding weight and dimensions, and the overweight should be measured by weighing equipment or by checking tax documents. Additionally, a percentage over the limits of the total gross weight and the gross weight transmitted by vehicle axle to the road surface is tolerated.

- $\quad$ Passenger or cargo vehicles will not travel with capacity or load above the limit defined by the manufacturer, and neither exceed the maximum traction capacity of the traction unit.

- Driving the vehicle with overweight, considering the tolerance percentage when measured by a weighing equipment, will result in a moderately serious offense with a fine increased every two hundred kilograms or a fraction of verified overweight, according to the law.

The Resolution No 210 of November 13, 2006, "defines the weight and dimension limits for vehicles travelling on roads and offers other provisions". According to DNIT (2015), the resolution establishes the maximum limits of Total Gross Weight and Total Gross Weight Combined (Table 2).

Table 2: Maximum Weights: Resolution $\mathrm{n}^{\circ}$ 12/98, Article 2

\begin{tabular}{cccccc}
\hline Axle & Rolling & Suspension & Wheelbase $(\mathrm{m})$ & Load $(\mathrm{kg})$ & Tolerance $(7.5 \%)$ \\
\hline Single & Single & Directional & - & $6,000^{(1)}$ & 6,450 \\
Single & Single & Directional & - & $6,000^{(2)}$ & 6,450 \\
Single & Double & - & - & 10,000 & 10,750 \\
Double & Single & Directional & - & 12,000 & 12,900 \\
Double & Double & Tandem & $>1.20$ or $\leq 2.40$ & 17,000 & 18,280 \\
Double & Double & Not tandem & $>1.20$ or $\leq 2.40$ & 15,000 & 16,130 \\
Double & Single + Double & Especial & $<1.20$ & 9,000 & 9,680 \\
Double & Single + Double & Especial & $>1.20$ or $\leq 2.40$ & 13,500 & 14,520 \\
Double & Extra-wide & Pneumatic & $>1.20$ or $\leq 2.40$ & 17,000 & 18,280 \\
Triple $^{(3)}$ & Double & Tandem & $>1.20$ or $\leq 2.40$ & 25,500 & 27,420 \\
Triple $^{(3)}$ & Extra-wide $^{(4)}$ & Pneumatic & $>1.20$ or $\leq 2.40$ & 25,500 & 27,420 \\
\hline
\end{tabular}

(1) For wheels with a diameter less than or equal to $830 \mathrm{~mm}$; (2) Observed the capacity and weight limits indicated by the tire manufacturer and diameter greater than $830 \mathrm{~mm}$; ${ }^{(3)}$ Applicable only to semi- 
DOI: 10.14807/ijmp.v7i5.419

trailers; (4) Single tire (385/65 R 22,5) applicable only to semi-trailers and trailers according to CONTRAN Resolution $n^{\circ} 62$ of 5/22/98. Source: DNIT (2015)

The Resolution No 211 of November 13, 2006, defines the necessary requirements for the circulation of Combinations of Cargo Vehicles (CCV) mentioned in Art. 97, 99 and 314 of the Brazilian Traffic Code, establishing, within the context of this research that the combinations with more than two units, including the traction unit, with total gross weight over 57 tons or total length over 19.80 meters, will only be able to circulate with a Special Traffic Authorization (STA).

The Article II of the Resolution defines the minimum requirements for a special traffic authorization, which will not be the object of this research because it represents an insignificant share in terms of road traffic.

Regarding the load configuration, the DENATRAN Decree no 63 of March 31, 2009, homologous the vehicles and combinations of cargo and passenger vehicles specifying the limits of length, total gross weight (PBT) and total combined gross weight (PBTC). After, the DENATRAN Decree no 63 was issued and it was possible to observe the types of load vehicles and the combinations with their respective weight limits.

The Law 7.408 of November 25, 1985 establishes the tolerance of $5 \%$ when weighing the load of transport vehicles. According to DNIT (2015) the tolerance aims to address the uncertainty of the measurement equipment. The CONTRAN Resolution $n^{\circ} 258 / 07$ "regulates the articles 231, X and 323 of the Brazilian Traffic Code, establishes the methodology of measuring the vehicles' weight, defines tolerance percentages and makes other provisions".

The Resolution $n^{\circ} 258 / 07$ brings back the fine by axle, which had been suspended by the Resolution $n^{\circ} 104 / 99$. Up to 31 January, 2008 the Resolution $n^{\circ}$ $258 / 07$ accepted a tolerance of $7.5 \%$ (seven and a half percent) by axle. After that, the tolerance by axle will be of $5 \%$ (five percent).

The Resolution $n^{\circ} 258 / 07$ also establishes, regardless of the type of load, limits by axle that allow the vehicle's travel to continue without the need of relocation or overflow after an overweight fine is applied. The Resolution establishes that the tolerance is valid for the equipment ("scale") and cannot be incorporated during the loading. Whoever uses the tolerance during loading would be illegally increasing its 
DOI: 10.14807/ijmp.v7i5.419

limits, thus reducing the tolerance intended for scale faults and considerably increasing the risk of getting a fine. Additionally, the $5 \%$ (five percent) tolerance was abolished during invoice checking; this tolerance was previously defined by the now revoked Resolution $n^{0} 104 / 99$, which only allowed verification through the invoice on roads where there were no scales. Now, when there is no scale, the measurement can be made at any time or place through the weight declared in the invoice, waybill or cargo manifest, and no tolerance is allowed regarding the declared weight.

Besides the changes mentioned above, the Resolution $n^{\circ}$ 258/07 established a fine to vehicles that travel with a load above the Maximum Traction Capacity (MTC) defined by the manufacturer. Finally, it clearly defines the shipper as the load sender or dispatcher, even if it is freight collect.

According to CONTRAN Resolution $n^{\circ} 365 / 10$ the deadline of December 31, 2011 defined by article 17 of the CONTRAN Resolution $n^{\circ}$ 258/07 was extended. Therefore, the maximum tolerance of $7.5 \%$ (seven and a half percent) over the limits of gross weight transferred by the axles to road surfaces will still be allowed. After that date, the maximum tolerance will again be $5 \%$ (five percent).

\subsection{Weighing of commercial vehicles}

According to DNIT (2006) the weighing operation consists of weight checking by axle or set of axles and of the total gross weight, performed at the weighing sites using mobile or fixed scales located in an area of the road that doesn't disturb the flow of vehicles. Also, according to DNIT, the weighing shall follow these guidelines:

- Weighing platform: place at the weighing sites where the scales are installed;

- $\quad$ Selective scale: equipment intended to select vehicles with a probable overweight, directing them to the low-speed static or dynamic weighing;

- Static mobile scales: consists basically of two (2) plates over which the axles are statically weighted;

- Dynamic mobile scales: consists basically of two (2) plates over which the vehicle's axles are weighted at a speed of up to $10 \mathrm{~km} / \mathrm{h}$;

- Static fixed scales: consists basically of one (1) plate over which the vehicle stops with all its axles and it is weighted statically; 
- Dynamic fixed scales: consists basically of one (1) plate over which the vehicle is weighted at a speed of up to $10 \mathrm{Km} / \mathrm{h}$;

- Transit authority agent: civil or military individual who is certified by the traffic authority to perform the supervision, operation, overt traffic policing and patrolling activities;

- Weighing infraction notice: document issued at weighing operations, indicating that the total gross weight or the total gross combined weight, according to the model, exceeded the limits;

- Infraction notice of Maximum Traction Capacity (MTC): document issued at weighing operations, indicating that the Maximum Traction Capacity was exceeded;

- Total Gross Weight (TGW): maximum weight that the vehicle transmits to the pavement, consisting of the tare plus the capacity;

- Total Gross Combined Weight (TGCW): maximum weight transmitted to the pavement by the combination of a tractor-truck and its semi-trailer or a truck and its trailer or trailers;

- Maximum Traction Capacity (MTC): maximum weight that the traction unit is capable of driving, indicated by the manufacturer, based on its limitations to generate and multiply the momentum and the resistance of the elements that are parts of the transmission system;

- $\quad$ Capacity: maximum payload, including the driver and passengers that the vehicle carries, expressed in kilograms for cargo vehicles or the number of people for passenger vehicles;

- Tare: vehicle's own weight plus the weight of the body and equipment, fuel, tools and accessories, spare wheel, the fire extinguisher and the cooling fluid, expressed in kilograms;

Combination of cargo vehicle (CCV): combination of more than two units, including the traction unit, and/or a length range between 18.15 and 30.00 meters, and/or a total gross combined weight between 45.0 and 74.0 tons. 
DOI: 10.14807/ijmp.v7i5.419

\subsection{Tires}

The inflation pressure range recommended by Pirelli, between 750 and 800 $\mathrm{kPa}$, is the most significant within the universe of commercialized tires. In order for an actual verification it would be necessary to know the sales percentage of each type of tire and to check, using other tools, the actual inflation pressure. However, this gives us a comprehensive parameter of the actual inflation pressure acting on the pavement.

To better visualize the inflation pressures recommended by Pirelli a chart was prepared showing the pressure range vs. the percentage of commercialized tires, Figure 1.

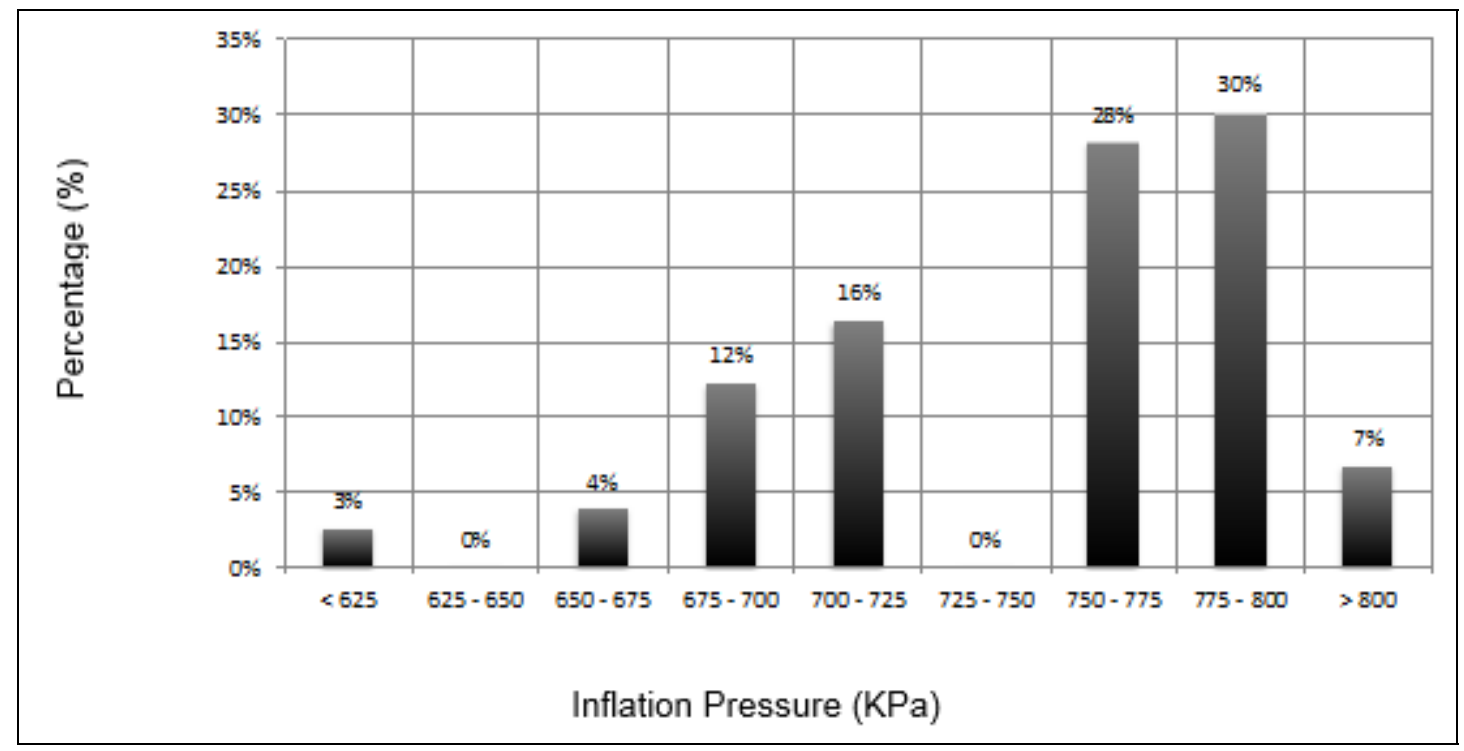

Figure 1: Pressure range vs. commercialization Source: Adapted from Pirelli (2015).

The inflation pressure data are provided by Pirelli according to the type of tire and some types of vehicles based on the classification defined by DENATRAN Decree No 63/2009. This data can be visualized in the manufacturer's website.

\section{METHODOLOGY}

\subsection{Methods to calculate the "N" number and its variables}

The "N" number is calculated using the following Equation 1:

$N=365 \times P \times V D M \times F V \times F R \times D \times d$

Where, $\mathrm{N}=$ number of solicitations equivalent to the standard axle; $\mathrm{P}=$ project period; $\mathrm{VDM}=$ daily average traffic volume; $\mathrm{FV}=$ vehicle factor; $\mathrm{FR}$ = regional climate 
DOI: 10.14807/ijmp.v7i5.419

factor; $D=$ percentage of commercial vehicles in the busiest lane; $d=$ percentage of vehicles in each way.

Once defined a 10-year period, according to the guidelines of the Department of Roads of the State of São Paulo (DER/SP), the determination of the $\mathrm{N}$ number consists, at first, of defining the traffic volumes of each type of vehicle and its growth forecast.

The second stage of calculation is to define the vehicle factor (FV), which allows the determination of the number of axles that are equivalents to the standard axle based on the volume of vehicles with a particular configuration of axles and loads that travel during the project period. The vehicle factor is calculated using the Equation 2:

$$
F V=F E \times F C
$$

Where, $\mathrm{FE}=$ axle factor; $\mathrm{FC}=$ load equivalency factor.

The maximum loads by type of axle as defined by the Scale Act and the Brazilian Traffic Code (Law no 9.053 of 09/23/1997 - resolution no 12 of 02/06/1998) corresponds to $6.0 \mathrm{tf}$ on the single front axle, and $10.0 \mathrm{tf}, 17.0 \mathrm{tf}$ and $25.5 \mathrm{tf}$ on the single, double tandem and triple tandem rear axles, respectively.

The equivalency factors to the standard load of $8.2 \mathrm{tf}$ are analytically determined through two calculation methods, one from USACE (United States Army Corps of Engineers) and the other from AASHTO (American Association of State Highway and Transportation Officials, 1972 and 1983), the former is proposed by $\mathrm{DER} / \mathrm{SP}$ and the latter for the purpose of mechanistic evaluation.

According to the sizing procedure of DER/SP, in order to consider the variations of humidity of the materials that constitute the pavement during the seasons of the year (resulting in variations of the capacity of material support), one must multiply the equivalent number of solicitations of the standard axle (or traffic parameter) "N" by a "FR" coefficient, called Regional factor, which, on the experimental AASHTO lane, ranged from 0.2 (low level of humidity) to 5.0 (materials are virtually saturated).

In Brazil there are no experimental elements for that determination, but according to DER/SP recommendations, one can adopt $F R=1.0$. 
DOI: 10.14807/ijmp.v7i5.419

\subsection{Verification of the pavement structures through the elasticity theory}

The vehicles' loads generate tensions and deformations inside the pavement structure. These tensions and deformations are a function of the load magnitude, the resilient modules, the thickness of the pavement layers and the sub base's support capacity.

Therefore, the acting shifts and deformations that originate inside the loaded pavement were determined in order to be compared with the allowable shifts and deformations value and that are a function of the type of material used in the pavement structure.

In order to determine the internal efforts, the deformations and shifts of the flexible pavement structure the computer program ELSYM 5 (Elastic Layered System) was used, which takes into account the constant elastic characteristics for each layer of the pavement structure. The parameters were used to calculation:

- Load of the standard single axle of $80 \mathrm{kN}$, represented by $4 \times 20 \mathrm{kN}$;

- Tire/Pavement contact pressure of $5.6 \mathrm{kgf} / \mathrm{cm}^{2}$;

- $\quad \mathrm{CBUQ}$ Resilience Module (Coating) of $35,000 \mathrm{kgf} / \mathrm{cm}^{2}$;

- $\quad$ Simple Graded Gravel Resilience Module of $3,000 \mathrm{kgf} / \mathrm{cm}^{2}$;

- $\quad$ Cracked Rock Resilience Module of 2,500 kgf/ $\mathrm{cm}^{2}$;

- Resilience Module of the subbase of $700 \mathrm{kgf} / \mathrm{cm} 2$ for $\mathrm{CBR}=7 \%$

Where CBUQ: Hot Mix Asphalt Concrete; kN: kilo Newton; CBR: California Bearing Ratio; $\mathrm{kgf} / \mathrm{cm}^{2}$ : kilogram-force per square centimeter.

The internal shifts and deformations of the pavement structure were determined at their critical places: at the top of the asphalt concrete layer (vertical shift), at the lower fiber of the asphalt concrete layer (traction horizontal deformation) and at the top of the sub base (compression vertical deformation).

In order to determine the allowable efforts the following fatigue equations 3,4 and 5 were used.

Vertical shift at the pavement surface - deflection - D0 (x10-2 mm) (DNERPRO 11, 1979): 
DOI: 10.14807/ijmp.v7i5.419

$\log D_{0_{a d m}}=3,01-0,176 \times \log N$

Traction horizontal deformation at the coating lower fiber - et $(x 10-4 \mathrm{~cm} / \mathrm{cm})$. FHWA:

$$
N=1,09 \times 10^{-6} \times\left(\frac{1}{\varepsilon_{\text {tadm }}}\right)^{3,512}
$$

Compression vertical deformation at the top of the sub base layer $-\mathrm{eV}(\mathrm{x} 10-4$ $\mathrm{cm} / \mathrm{cm}$ ). Shell (Dormon and Metcalf)

$$
N=6,069 \times 10^{-10} \times\left(\frac{1}{\varepsilon_{v_{a d m}}}\right)^{4,762}
$$

The values obtained by the software are used in fatigue equations shown above for each layer of the pavement and, as indicated, the "N" number is found for the period.

\section{RESULT AND DISCUSSION}

\subsection{Influence of the calculation variables on the result of the $\mathbf{N}$ number}

$\mathrm{N}$ number $=$ number of solicitations equivalent to those of a standard road axle (ESRD) of $8.2 \mathrm{tf}(80 \mathrm{kN})$ for the project period. According to IP-DE-P00/001 - DER/SP Paving Project, in order to mechanistically verify the pavement structure one must know the parameters regarding the support capacity of the sub base soils and the expected traffic for the period, as well as the properties of the materials that constitute the layers of the pavement structure and the fatigue models for such materials. The loads to be included in the mechanistic analysis should simulate the standard dual wheel single axle of $80 \mathrm{kN}$, using four points of load application (20 kN each) and the tire-pavement contact pressure of $0.56 \mathrm{MPa}$.

The mechanistic analysis of the pavement structure uses material fatigue models that calculate their limitations through the above-mentioned parameters.

It is necessary to understand how and under which conditions the mathematical expressions of material fatigue were obtained in order to consider them in the evaluation of the quality and performance of a particular pavement. 
DOI: 10.14807/ijmp.v7i5.419

\subsection{Performance of asphaltic pavements}

The pavement performance evaluation was developed based on the criterion of deform-ability of flexible pavements, expressed by measuring the recoverable deflections since its experience has shown there is a correlation between the magnitude of the deflections (and of the corresponding radius of curvature) and the occurrence of failures in flexible pavements.

The behavior of a well-built pavement depends on the various solicitations it suffers throughout its lifespan, including the traffic that results in different efforts of compression, shearing and flection, as well as climate factors such as rains and temperature changes that cause fatigue on the entire structure.

Regarding the deflection, the following phases of a pavement life cycle can be observed:

- Consolidation phase: a phase right after the construction and that is characterized by a slow decrease of the deflection value due to the additional consolidation through the traffic on the various pavement layers. The deflection values tend to estabilize at the end of this phase.

- Elastic phase: a phase that comes after the consolidation phase and along which the pavement deflection value, excluding the seasonal variations, remains approximately constant or increases slightly. This phase defines the pavement service life, which tends to increase according to the difference verified between the allowable deflection and the deflection tolerated by the pavement.

- Fatigue phase: a phase that comes after the elastic phase and is characterized by a fast increase in the pavement deflection value as the structure starts showing the fatigue effects represented by fissures, cracks and accumulation of permanent deformation under repeated loads. If no measures are taken to reinforce and recover the pavement, usually the result is a degradation process. Figure 2 illustrates the phases of a pavement life cycle described above. 


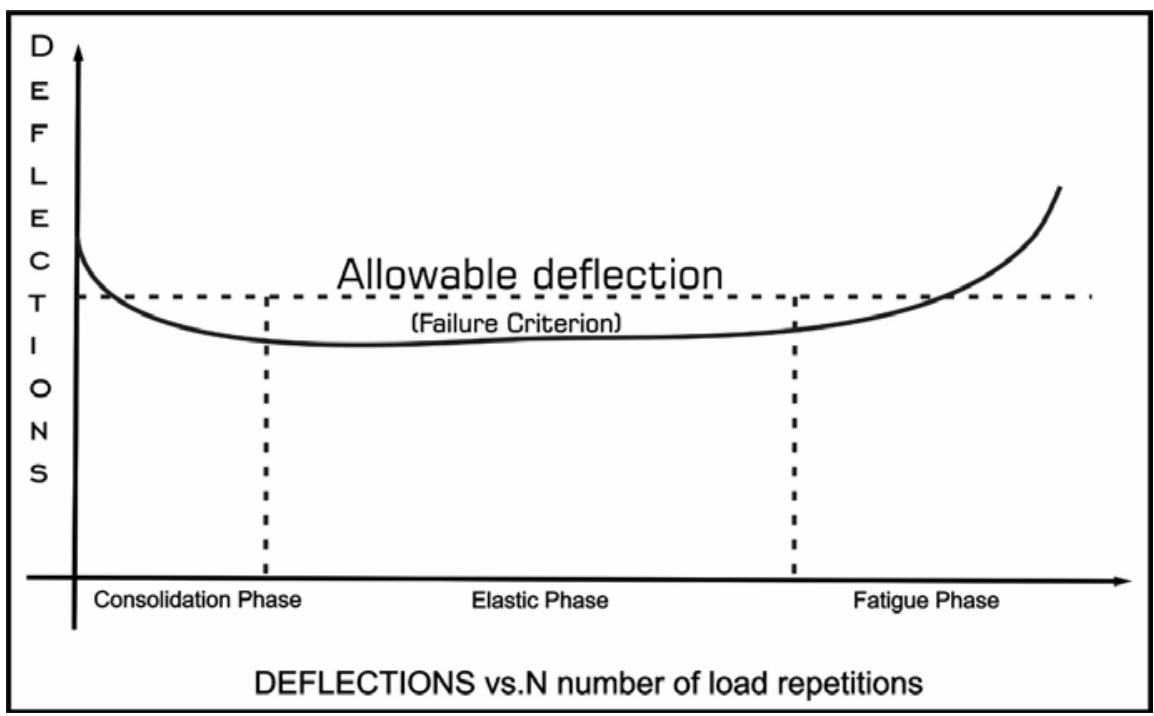

Figure 2: Phase of a pavement life cycle. Source: DER/SP PRO 11/79 (1979).

The flexible pavement will be technically and economically better than longer elastic phase.

The allowable deflection value depends on the materials that constitute the coating and the base of the pavement, as well as on the $\mathrm{N}$ number of solicitations of axels that equivalent to the standard axle of $80 \mathrm{kN}$. Figure 3 shows the criteria for a structural evaluation, associating the allowable deflections with the pavement state.

\begin{tabular}{|c|c|c|c|c|c|}
\hline Hypothesis & $\begin{array}{c}\text { Collected } \\
\text { deflection data }\end{array}$ & $\begin{array}{l}\text { Structural } \\
\text { quality }\end{array}$ & $\begin{array}{l}\text { Need of } \\
\text { complimentary } \\
\text { studies }\end{array}$ & $\begin{array}{l}\text { Criterion for } \\
\text { reinforcement } \\
\text { calculation }\end{array}$ & $\begin{array}{l}\text { Corrective } \\
\text { measures }\end{array}$ \\
\hline$T$ & $\begin{array}{c}\text { Dc }<\text { Dadm } \\
R>100\end{array}$ & GOOD & NO & & $\begin{array}{c}\text { Surface } \\
\text { corrections only }\end{array}$ \\
\hline III & $\begin{array}{c}\text { Dc }>\text { Dadm } \\
R>100\end{array}$ & $\begin{array}{l}\text { If } \mathrm{Dp}<3 \\
\text { Dadm } \\
\text { REGULAR } \\
\text { If } \mathrm{Dp}>3 \\
\text { Dadm } \\
\text { BAD }\end{array}$ & $\begin{array}{l}\text { NO } \\
\text { YES }\end{array}$ & $\begin{array}{l}\text { Deflectometric } \\
\text { Deflectometric } \\
\text { and Resistance }\end{array}$ & $\begin{array}{l}\text { Reinforcement } \\
\text { Reinforcement or } \\
\text { Reconstruction }\end{array}$ \\
\hline III & $\begin{array}{c}\text { Dc }<\text { Dadm } \\
\mathrm{R}<100\end{array}$ & $\begin{array}{l}\text { REGULAR } \\
\text { TO BAD }\end{array}$ & YES & $\begin{array}{l}\text { Deflectometric } \\
\text { and Resistance }\end{array}$ & $\begin{array}{l}\text { Reinforcement or } \\
\text { Reconstruction }\end{array}$ \\
\hline IV & $\begin{array}{c}\text { Dc }>\text { Dadm } \\
R<100\end{array}$ & BAD & YES & Resistance & $\begin{array}{l}\text { Reinforcement or } \\
\text { Reconstruction }\end{array}$ \\
\hline V & - & $\begin{array}{c}\text { BAD } \\
\text { The pavement } \\
\text { shows } \\
\text { permanent } \\
\text { deformations } \\
\text { and } \\
\text { generalized } \\
\text { plastic rupture } \\
\text { (IGG > 180) }\end{array}$ & YES & Resistance & Reconstruction \\
\hline
\end{tabular}

Figure 3: Criteria for a structural evaluation. Source: DER/SP PRO 11/79 (1979). 
DOI: 10.14807/ijmp.v7i5.419

This study used the AASHTO and USACE methodologies. The pavement structure chosen for the study consists of a $5.0 \mathrm{~cm}$ thick layer of CBUQ Band III, followed by a $5.0 \mathrm{~cm}$ thick layer of CBUQ Band II, a $20.0 \mathrm{~cm}$ thick layer of Simple Graded Gravel as base and a $30.0 \mathrm{~cm}$ thick layer of Dry Bound Macadam as sub base. Figure 4 illustrates the pavement of this study.

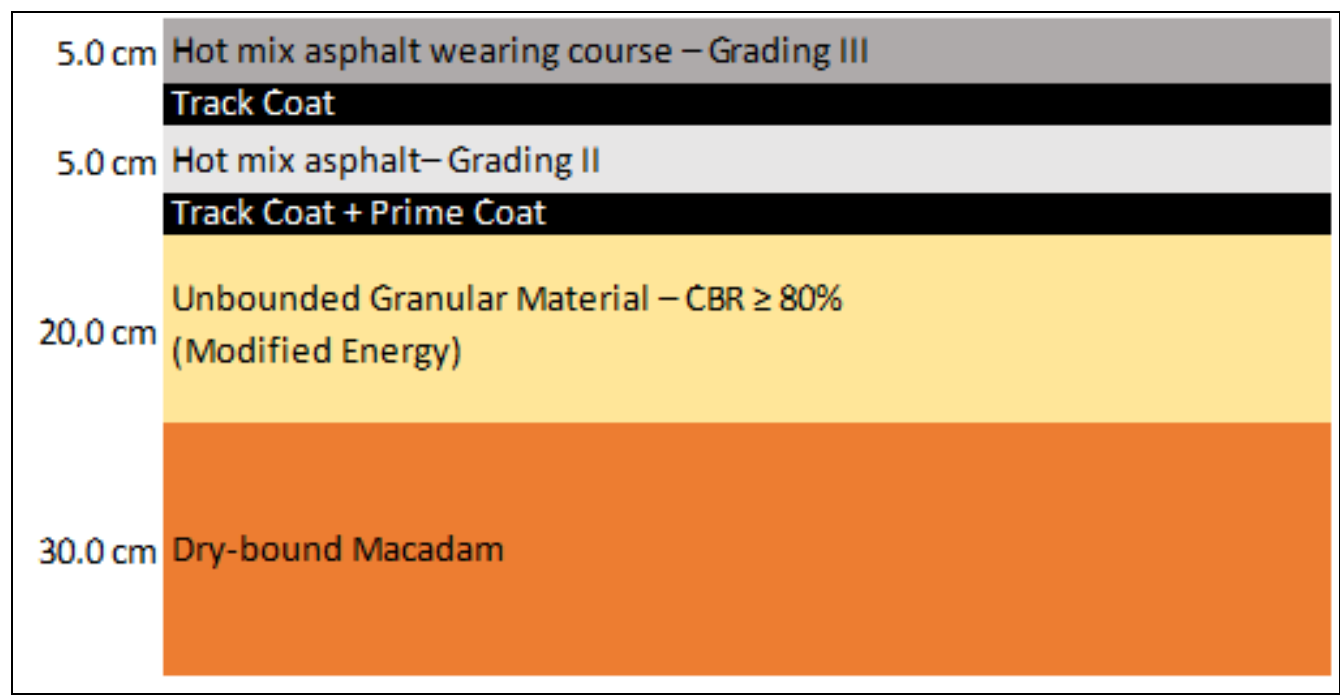

Figure 4: Structure for the study. Source: Author (2015).

Table 3 shows the simulation of road cost per linear meter using the DER/SP single price table of 03/31/2015, considering the structure analyzed in this study.

Table 3: Selected structure - quantitative (Single Price Table - DER/SP 03/31/2015)

\begin{tabular}{|c|c|c|c|c|c|c|c|c|c|c|}
\hline Item & Service & UN & $\begin{array}{l}\text { EX } \\
(m)\end{array}$ & $\begin{array}{l}\text { WID } \\
(\mathrm{m})\end{array}$ & $\begin{array}{l}\text { AR } \\
\left(m^{2}\right)\end{array}$ & COEF & $\begin{array}{l}\text { THI } \\
(\mathrm{m})\end{array}$ & QTY & $\begin{array}{l}\text { UV } \\
(R \$)\end{array}$ & $\begin{array}{c}\text { TOTAL } \\
(\mathrm{R} \$)\end{array}$ \\
\hline 23.02 .02 & $\begin{array}{l}\text { Improving/Preparing } \\
\text { subbase - } 100 \% \mathrm{Ei}\end{array}$ & $\mathrm{m} 2$ & 1 & 7 & 7 & 1.20 & t & 8.40 & 1.63 & 13.69 \\
\hline 23.04.06.03 & Dry Bound Macadam & m3 & & & & & & & & \\
\hline & Subbase or Base & & 1 & 7 & 7 & 1.15 & 0.30 & 2.42 & 168.37 & 406.61 \\
\hline 23.04.03.01 & $\begin{array}{l}\text { Simple Graded Gravel } \\
\text { Subbase or Base }\end{array}$ & m3 & 1 & 7 & 7 & 1.10 & 0.20 & 1.54 & 178.14 & 274.34 \\
\hline 23.05 .02 & $\begin{array}{l}\text { Binding Bituminous } \\
\text { Priming }\end{array}$ & $\mathrm{m} 2$ & 1 & 7 & 7 & 1.08 & - & 7.56 & 2.28 & 17.24 \\
\hline $\begin{array}{l}23.05 .01 \\
23.08 .02\end{array}$ & $\begin{array}{l}\text { Sealing Bituminous } \\
\text { Priming } \\
\text { Hot Mix Asphalt Conc }\end{array}$ & $\mathrm{m} 2$ & 1 & 7 & 7 & 1.08 & - & 7.56 & 4.58 & 34.62 \\
\hline 23.05 .02 & $\begin{array}{l}\text { - BinderGrad.B w/Dop } \\
\text { Binding Bituminous Priming }\end{array}$ & $\mathrm{m} 2$ & 1 & 7 & 7 & 1.05 & 0.05 & 0.37 & 585.43 & 215.15 \\
\hline 23.08.03.03 & $\begin{array}{l}\text { Rolling Layer - CBUQ } \\
\text { - Grad.C - w/Dop }\end{array}$ & $\mathrm{m} 3$ & 1 & 7 & 7 & 1.05 & 0.05 & 7.35 & 659.83 & 16.76 \\
\hline
\end{tabular}

$\mathrm{UN}=$ Unity; $\mathrm{EX}=$ Extension; $\mathrm{WID}=$ Width; $\mathrm{AR}=$ Area; $\mathrm{COEF}=$ Overwidth Coefficient; THI =

Thickness; QTY = Quantity; UV = Unit Value. Source: Author (2015) 
INDEPENDENT JOURNAL OF MANAGEMENT \& PRODUCTION (IJM\&P)

http://www.ijmp.jor.br

v. 7, n. 5, Special Edition IFLOG 2015

ISSN: 2236-269X

DOI: 10.14807/ijmp.v7i5.419

As can be seen in Table 3 and Figures 5, 6, 7, 8, 9 and 10 shown below, there is a significant decrease of the service life of the pavement that is the object of this study. As the axle load applied on the contact pressure between the tires and the road surface increases, the durability calculation projected on the $\mathrm{N}$ number decreases, resulting in premature fatigue of the pavement structure and a possible need to repair or even rebuild the road before the 10-year period required by the rule in effect.

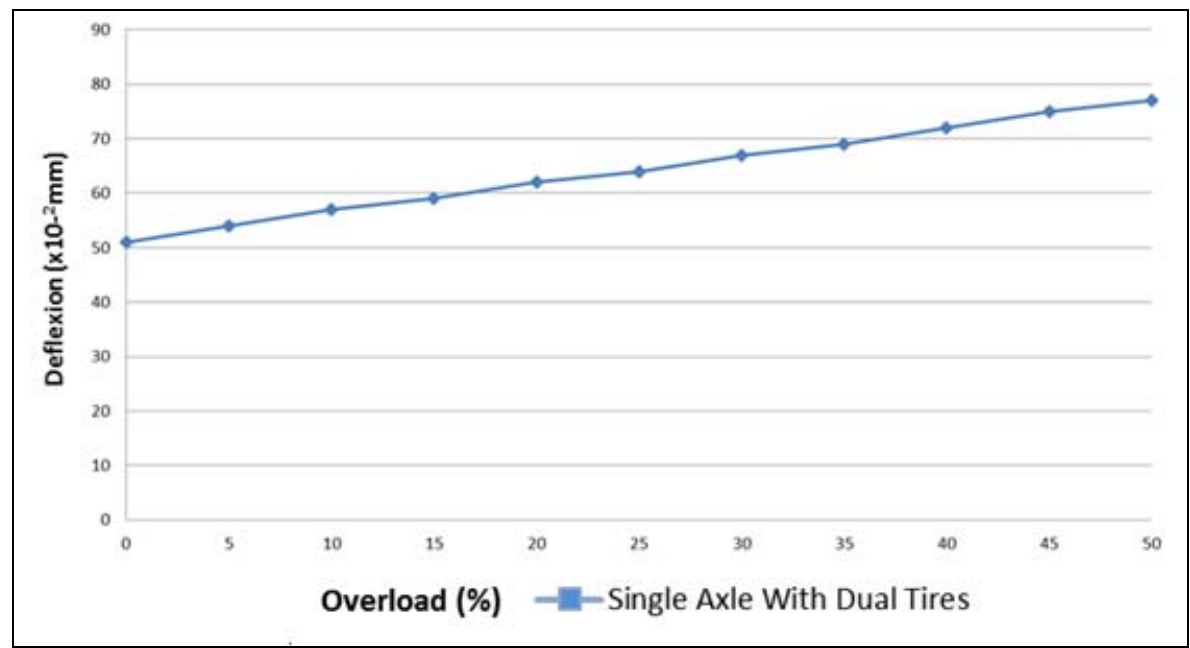

Figure 5: Deflection vs. Overload for single axle with dual tires. Source: Author (2015)

Figure 6: Damage to the service life (Deflection) vs. Overload for single axle with dual tires.

Source: Author (2015) 
INDEPENDENT JOURNAL OF MANAGEMENT \& PRODUCTION (IJM\&P)

http://www.ijmp.jor.br

v. 7, n. 5, Special Edition IFLOG 2015

ISSN: 2236-269X

DOI: 10.14807/ijmp.v7i5.419

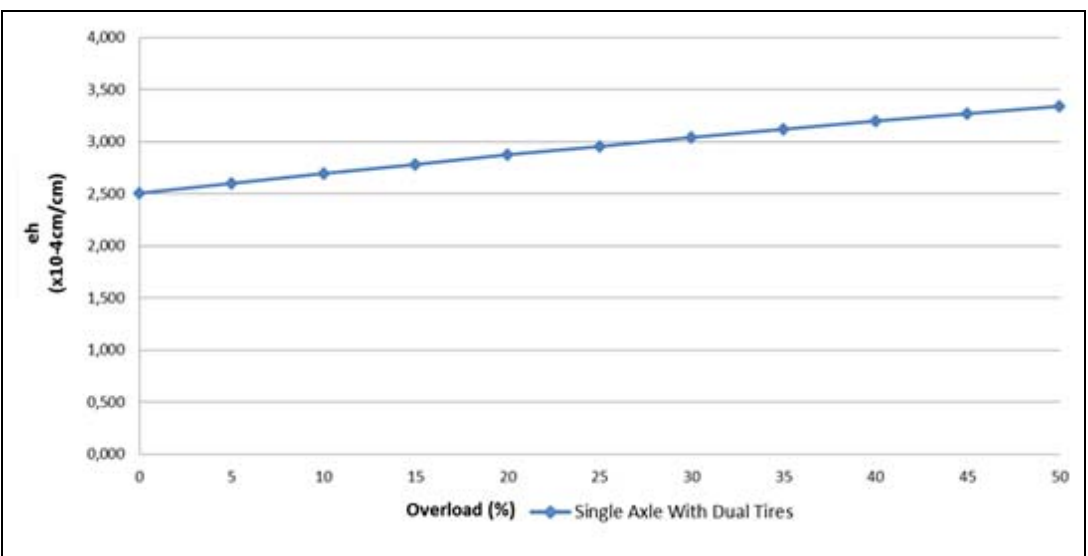

Figure 7: Tensile strain at the bottom of the asphalt layer vs. Overload for single axle with dual tires.

Source: Author (2015)

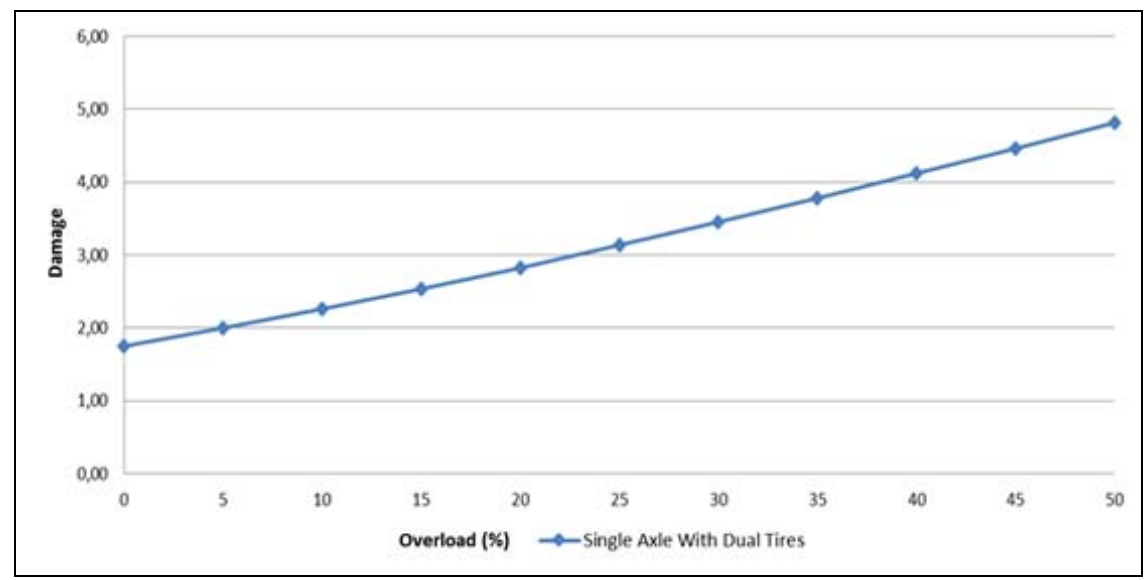

Figure 8: Damage to service life (Tensile strain at the bottom of the asphalt layer) vs. Overload for Single Axle With Dual Tires.

Source: Author (2015)

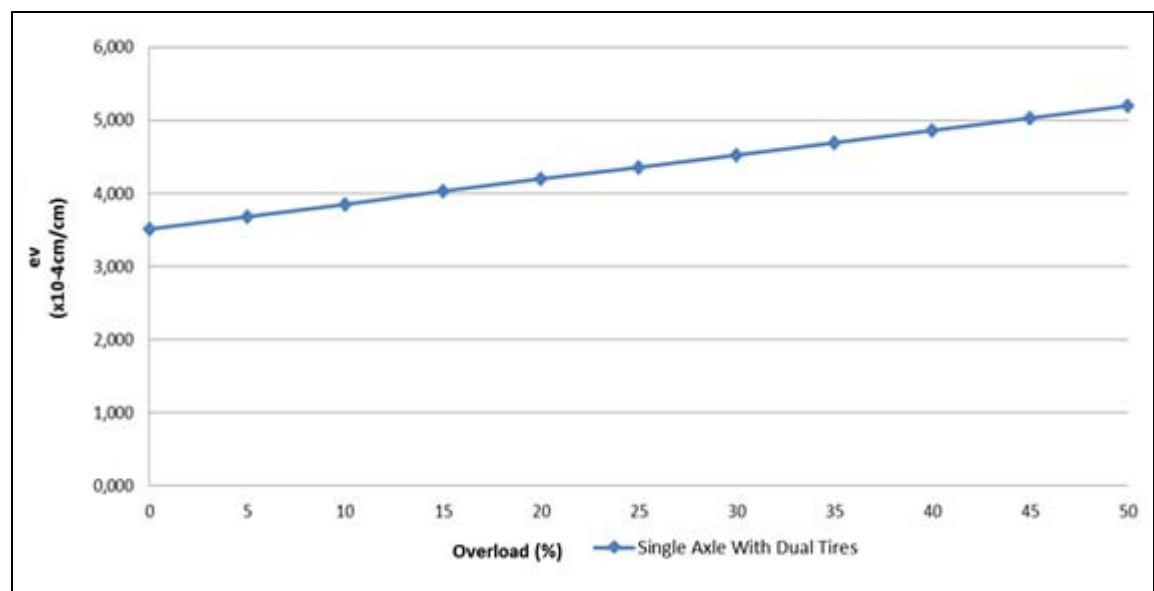

Figure 9: Vertical compressive strain on the subgrade vs. Overload for single axle with dual tires.

Source: Author (2015) 


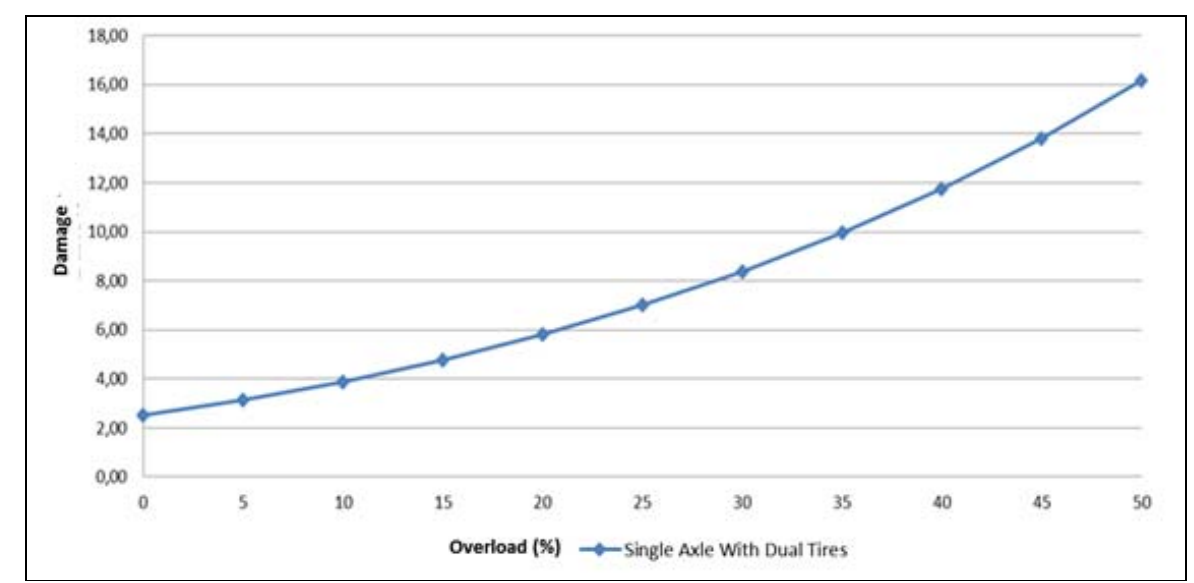

Figure 10: Damage to service life (compressive strain on the subgrade) vs. Overload for single axle with dual tires.

Source: Author (2015)

\section{CONCLUSION}

The present study shows the need for a strict control through the use of scales of commercial vehicles loads that travel on roads. One might also suggest measuring the tire pressure so that it complies with the standard values used in calculations of pavement design established by relevant state and federal government entities.

\section{REFERENCES}

AASHTO. (1972) Guide for design of pavement structures. American Association of State Highway and Transportation Officials, Washington, D.C. USA.

AASHTO. (1993) Guide for design of pavement structures. American Association of State Highway and Transportation Officials, Washington, D.C, USA.

AL-QADI, I.L.; ELSEIFI, M.A. (2007) New generation of wide-base tire and its impact on trucking operations, environment, and pavements. Journal of the Transportation Research Board, v. 2008, p. 100-1009.

BALBO, J. T. (2007) Pavimentação asfáltica: materiais, projeto e restauração. São Paulo: Oficina de Textos.

BNDES, BANCO NACIONAL DE DESENVOLVIMENTO ECONÔMICO E SOCIAL. 2008. Available at: <http://www.bndes.gov.br/SiteBNDES/bndes/bndes_pt/Areas_de_Atuacao/Infraestrut ura/Logistica/index.html>. Accessed in August, $201 \overline{5}$.

BARTHOLOMEU, D. B. (2006) Quantificação dos impactos econômicos e ambientais decorrentes do estado de conservação das rodovias brasileiras, Tese de doutorado, Escola Superior de Agricultura Luiz de Queiroz, Universidade de São Paulo, Piracicaba, 164p.

BERNUCCI, L.B. et al. (2006) Pavimentação Asfáltica: formação básica para engenheiros, Rio de Janeiro: PETROBRAS: ABEBA.

BRAZIL. (2015) Law no 9.503/97 - Código de Trânsito Brasileiro. Available at: http://www.planalto.gov.br/ccivil_03/LEIS/L9503.htm. Accessed in September, 2015. 
CNT, CONFEDERAÇÃO NACIONAL DOS TRANSPORTES. (2012) Available at: <http://www.cnt.org.br/Paginas/Boletins.aspx>. Accessed on August, 2015.

CONTRAN, CONSELHO NACIONAL DE TRÂNSITO. (2006) Resolution 210/06. Available at: http://www.denatran.gov.br/download/Consolidadas/cons210.pdf. Accessed in September, 2015.

CONTRAN, CONSELHO NACIONAL DE TRÂNSITO. (2006) Resolution 211/06. Available at: http://www.denatran.gov.br/download/Consolidadas/cons211.pdf. Accessed in September, 2015.

CONTRAN, CONSELHO NACIONAL DE TRÂNSITO. (2007) Resolution 258/07. Available at: http://www.denatran.gov.br/download/Resolucoes/RESOLUCAO_CONTRAN_258.pd f. Accessed in September, 2015.

CONTRAN, CONSELHO NACIONAL DE TRÂNSITO. (2010) Resolution 365/10. Available at: http://www.denatran.gov.br/download/Resolucoes/RESOLUCAO_CONTRAN_365_1 0.pdf. Accessed in September, 2015.

DENATRAN. (2009) Decree $n^{\circ}$ 63/2009. Available at: http://www.denatran.gov.br/download/Portarias/2009/PORTARIA_DENATRAN_63_0 9_ANEXOS.pdf. Accessed in September, 2015.

DNER, DEPARTAMENTO NACIONAL DE ESTRADAS E RODAGENS. (1979) Avaliação Estrutural de Pavimentos Flexíveis. DNER-PRO11/79, Rio de Janeiro.

DNER, DEPARTAMENTO NACIONAL DE ESTRADAS E RODAGENS. (1996) Manual de pavimentação, Rio de Janeiro.

DNER, DEPARTAMENTO NACIONAL DE ESTRADAS DE RODAGEM (1998) Manual de reabilitação de pavimentos asfálticos. Rio de Janeiro.

DNIT. (2015) Law $\mathrm{n}^{\circ}$ 7.408/85. Legal weight limitations. Available at: http://www1.dnit.gov.br/Pesagem/Arq_pdf/INSTRUCOES.pdf. Accessed in September, 2015.

DNIT, DEPARTAMENTO NACIONAL DE INFRAESTRUTURA DE TRANSPORTES. (2006) Manual de Pavimentação, 3. ed. Rio de Janeiro.

FENG, W. (2005) Mechanistic-Empirical Study of Effects of Truck Tire Pressure on Asphalt Pavement Performance, Austin, Texas, USA: The University of Texas at Austin.

FERNANDES Jr., J.L. (1994) Investigação dos Efeitos das Solicitações do Tráfego sobre o Desempenho de Pavimentos. Doctoral Dissertation, EESC-USP.

HUANG, Y.H. (1993) Pavement Analysis and Design. Englewood Cliffs, New Jersey, USA: Prentice Hall.

IPEA, INSTITUTO DE PESQUISA ECONÔMICA APLICADA [INSTITUTE FOR APPLIED ECONOMIC RESEARCH]. (2010) Available at: $<$ http://www.ipea.gov.br/portal/index.php?option=com_alphacontent\&view=alphacont ent\&ltemid=357\&search=transporte+rodoviario>. Accessed in August, 2015.

KAWA, I.; HANG, Z.; HUDSON, W. (1997) Evaluation of the AASHTO 18-Kip Equivalency Concept .TEXAS, USA, Department of Transportation. 
MEDINA, J.; MOTTA, L.M.G. (2005) Resilient behavior of Brazilian tropical soils in pavement design. International Symposium On Pavement Evaluation And Overlay Design. Proceedings... Rio de Janeiro: ABPv, v. 1, p. 1.1.1-22. Mecânica dos pavimentos. 2. ed. Rio de Janeiro.

PINTO, S.; PREUSSLER, E. S. (2002) Pavimentação Rodoviária: conceitos fundamentais sobre pavimentos flexíveis, $2^{\mathrm{a}}$ ed., Rio de Janeiro, Copiarte Copiadora e Artes Gráficas Ltda.

PIRELLI. (2015) Faixa de pressão por comercialização. Available at: <http://www.pirelli.com/tyre/br/pt/truck_bus/catalog.>. Accessed in March, 2015.

SENÇO, W. (1997) Manual de técnicas de pavimentação, São Paulo: PINI. YODER, E.; WITCZAK, E.J.; WITCZAK, M.W. (1975) Principles of pavement design. 2. ed. New York: John Wiley \& Sons Inc. 